No 2012 - 21

October 2012

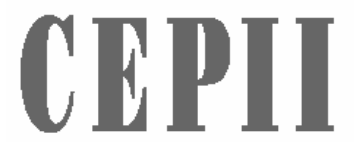

CENT TE

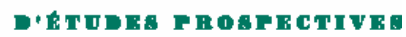

ET D'INOEMATIONS

INTEENATIONALES

Pegging emerging currencies in the face of dollar swings

Virginie Coudert

Cécile Couharde

Valérie Mignon 


\section{TABLE OF CONTENTS}

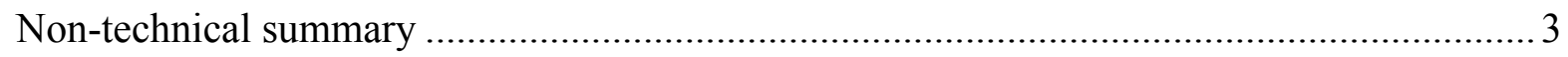

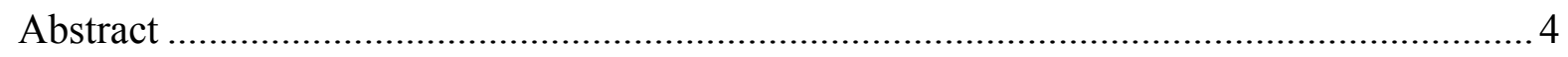

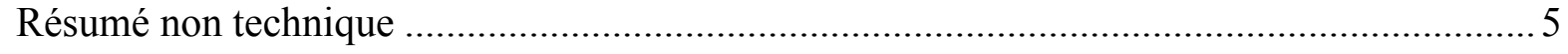

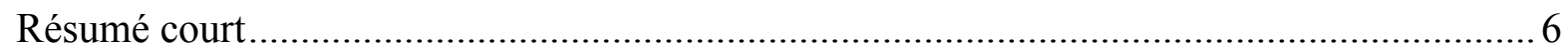

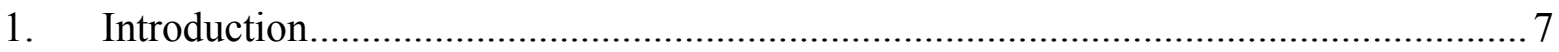

2. Ruptures of pegs and the role of the anchor currency ............................................ 9

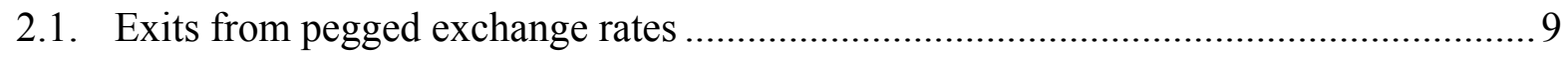

2.2. Rationales for choosing the USD as an anchor currency and adverse consequences... 10

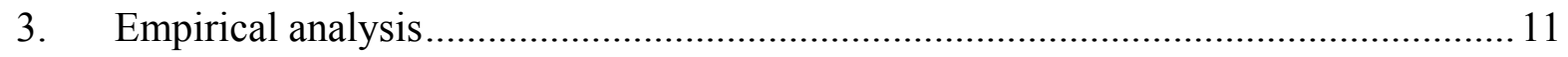

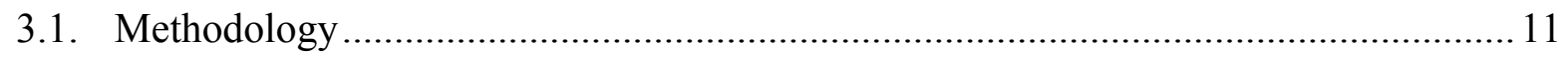

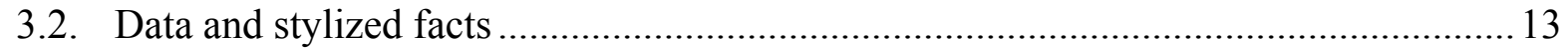

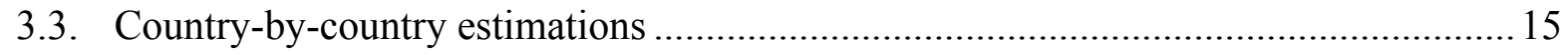

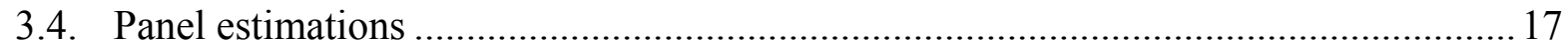

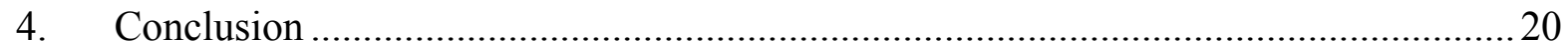

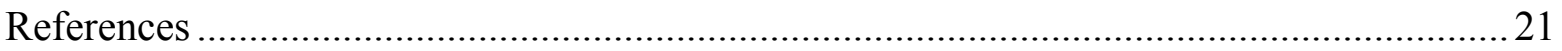

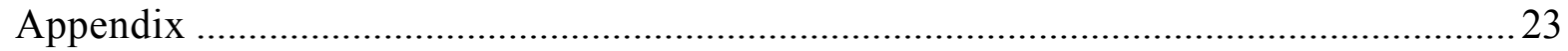

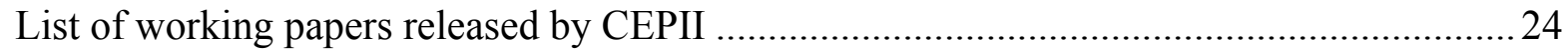




\title{
Pegging EMERging CURRENCIES IN THE FACE OF DOLLAR SWINGS
}

\author{
Virginie Coudert, Cécile Couharde, Valérie Mignon
}

\section{NON-TECHNICAL SUMMARY}

An extensive literature has been devoted to the choice of the exchange rate regime, and the question is still open given the pros and cons of every regime. On the one hand, pegged exchange rates are typically considered as not sustainable in the long run, as their average life-time is smaller than five years. On the other hand, most emerging countries have been following a more or less pegged exchange rate regime since the collapse of the Bretton Woods system.

One way to reconcile these two seemingly contradictory conclusions is to recognize that countries adapt their currency regime continuously according to their external environment. In particular, a large number of countries tend to follow pegged exchange rates, devalue under market pressures, and then come back to a fixed currency afterwards.

The rupture of pegs may stem from a variety of factors, such as deteriorating fundamentals inside the home country or pressures on global financial markets. In this paper, we focus on ruptures of pegs linked to the fluctuations of the anchor currency against third currencies. As most pegs have been adopted by countries willing to maintain their export competitiveness because of an export-oriented growth, pegging to an appreciating currency may appear detrimental. Indeed, it entails an appreciation of the home currency towards the rest of the world, and therefore of its real effective exchange rate. Consequently, it is not surprising that a number of countries untie their peg in periods when the anchor currency tends to appreciate against third currencies.

We test for the hypothesis that currencies linked to the USD are more likely to loosen their peg when the USD is appreciating, while sticking to it otherwise. To this end, we estimate smooth-transition regression models for a sample of 28 emerging currencies over the 19942011 period. Our findings show that while the real effective exchange rates of most of these countries tend to co-move with that of the USD in times of depreciation, this relationship is frequently reversed when the US currency appreciates over a certain threshold. Such nonlinear effects are especially at stake in Asia where growth is export-oriented. 


\begin{abstract}
The aim of this paper is to study ruptures of exchange-rate pegs by focusing on the fluctuations of the anchor currency. We test for the hypothesis that currencies linked to the USD are more likely to loosen their peg when the USD is appreciating, while sticking to it otherwise. To this end, we estimate smooth-transition regression models for a sample of 28 emerging currencies over the 1994-2011 period. Our findings show that while the real effective exchange rates of most of these countries tend to co-move with that of the USD in times of depreciation, this relationship is frequently reversed when the US currency appreciates over a certain threshold. Such nonlinear effects are especially at stake in Asia where growth is export-oriented.
\end{abstract}

JEL Classification: F31, F33, C22.

Key Words: $\quad$ real exchange rates, anchor currency, rupture of pegs, smooth transition regression models. 


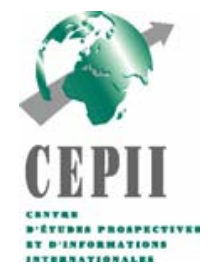

L’ANCRAGE DES DEVISES DES PAYS EMERGENTS FACE AUX FLUCTUATIONS DU DOLLAR

\author{
Virginie Coudert, Cécile Couharde, Valérie Mignon
}

\title{
RESUME NON TECHNIQUE
}

Une abondante littérature a été consacrée au choix du régime de change, mais la question reste ouverte, chaque régime comportant des avantages et des inconvénients. D'un côté, les régimes de taux de change fixes sont généralement considérés comme non viables à long terme, leur durée de vie moyenne étant inférieure à cinq ans. D'un autre côté, la plupart des pays émergents ont adopté un régime de change plus ou moins fixe depuis l'effondrement du système de Bretton Woods.

Une façon de concilier ces deux faits apparemment contradictoires est d'admettre que les pays adaptent continuellement leur régime de change en fonction de l'environnement extérieur. En particulier, un grand nombre de pays ont tendance à adopter des taux de change fixes, dévaluer sous les pressions du marché, puis revenir à une parité fixe par la suite.

Les ruptures d'ancrage peuvent provenir de divers facteurs, qu'il s'agisse de la détérioration des fondamentaux à l'intérieur du pays ou des pressions exercées par les marchés financiers internationaux. Dans cet article, nous nous concentrons sur les ruptures d'ancrage liées aux fluctuations de la monnaie ancre contre les monnaies tierces. Dans la mesure où la plupart des ancrages ont été adoptés par des pays désireux de maintenir leur compétitivité à l'exportation en raison d'une croissance axée sur les exportations, l'ancrage à une devise qui s'apprécie peut être préjudiciable. En effet, cela implique une appréciation de la monnaie nationale vis-à-vis du reste du monde, et donc de son taux de change effectif réel. Par conséquent, il n'est pas surprenant qu'un certain nombre de pays abandonnent leur ancrage pendant les périodes où la monnaie d'ancrage s'apprécie par rapport aux devises tierces.

Nous testons l'hypothèse selon laquelle les devises liées au dollar sont plus susceptibles de desserrer leur ancrage lorsque le dollar s'apprécie, tout en restant ancrées à la devise américaine en dehors de ses périodes d'appréciation. À cette fin, nous estimons des modèles de régression à transition lisse pour un échantillon de 28 monnaies de pays émergents sur la période 1994-2011. Nos résultats montrent que même si les taux de change effectifs réels de la plupart de ces pays évoluent de pair avec le dollar en période de dépréciation, cette relation est souvent inversée lorsque la devise américaine s'apprécie au delà d'un certain seuil. Ces 
effets non linéaires sont particulièrement marqués en Asie, où la croissance est tirée par les exportations.

\section{RESUME COURT}

L'objet de cet article est d'étudier les ruptures d'ancrage des taux de change en se concentrant sur les fluctuations de la monnaie d'ancrage. Nous testons l'hypothèse selon laquelle les devises liées au dollar sont plus susceptibles de desserrer leur ancrage lorsque le dollar s'apprécie, tout en restant ancrées à la devise américaine en dehors de ses périodes d'appréciation. À cette fin, nous estimons des modèles de régression à transition lisse pour un échantillon de 28 monnaies de pays émergents sur la période 1994-2011. Nos résultats montrent que même si les taux de change effectifs réels de la plupart de ces pays évoluent de pair avec le dollar en période de dépréciation, cette relation est souvent inversée lorsque la devise américaine s'apprécie au delà d'un certain seuil. Ces effets non linéaires sont particulièrement marqués en Asie, où la croissance est tirée par les exportations.

Classification JEL : F31, F33, C22.

Mots-clefs : $\quad$ taux de change réel, monnaie d'ancrage, rupture d'ancrage, modèles à transition lisse. 
PEgGiNG EMERging CURRENCIES IN THE FACE OF DOLLAR SWINGS

Virginie Coudert

Cécile Couharde ${ }^{* *}$

Valérie Mignon $^{* *}$

\section{INTRODUCTION}

In the present international monetary system, each country can freely choose its exchange rate regime, from a completely pegged to a floating currency, and change it without notice. This key policy choice is made according to the country's characteristics, as every regime has its pros and cons depending on the economic environment. An extensive literature has been devoted to this choice, and the question is still open as the two most famous papers on the topic seem to lead to conflicting conclusions. On the one hand, pegged exchange rates are typically considered as not sustainable in the long run, as their average life-time is smaller than five years (Obstfeld and Rogoff, 1995). On the other hand, most emerging countries have been following a more or less pegged exchange rate regime since the collapse of the Bretton Woods system (Calvo and Reinhart, 2002). One way to reconcile these two seemingly contradictory conclusions is to recognize that countries adapt their currency regime continuously according to their external environment. In particular, a large number of countries tend to follow pegged exchange rates, devalue under market pressures, and then come back to a fixed currency afterwards (Klein and Shambaugh, 2008). The rupture of pegs may stem from a variety of factors. First, pegs can break up because of deteriorating fundamentals inside the home country. Indeed, the peg itself may induce an overvaluation of the currency if domestic inflation is not subdued, which in turn brings about persistent current account deficits. Second, ruptures of pegs may occur under the pressures on global financial markets. This stems from huge amounts in carry trades on foreign exchange markets invested in emerging countries. When risk aversion rises on global financial markets, carry trades suddenly unwind; emerging currencies typically plummet along with most risky assets acrossthe-board. In these times of financial turmoil, pegs may turn impossible to defend (Coudert et al., 2011a; Coudert and Mignon, 2012).

In this paper, we explore another set of reasons for the rupture of pegs. This one is linked to the fluctuations of the anchor currency against third currencies. As most pegs have been

\footnotetext{
Bank of France, CEPII, and EconomiX-CNRS, University of Paris Ouest, France. Email: virginie.coudert@banque-france.fr.

EconomiX-CNRS, University of Paris Ouest, France. Email: cecile.couharde@u-paris10.fr.

Corresponding author: EconomiX-CNRS, University of Paris Ouest, and CEPII, France. Email: valerie.mignon@u-paris10.fr.

${ }^{1}$ See for example Baxter and Stockman (1989), Flood and Rose (1995), Rizzo (1998), Frankel (1999), and Alesina and Wagner (2006).
} 
adopted by countries willing to maintain their export competitiveness because of an exportoriented growth, pegging to an appreciating currency may appear detrimental. Indeed, it entails an appreciation of the home currency towards the rest of the world, and therefore of its real effective exchange rate (REER). This shortcoming is especially worrying if the country's exports are not mainly oriented towards the anchor country, as for Asian countries pegged to the USD (McKinnon, 2000; Kwack, 2004).

Consequently, it is not surprising that a number of countries untie their peg in periods when the anchor currency tends to appreciate against third currencies. There are two ways for this to happen. First, governments may be unable to maintain their peg under market attacks, because the appreciating anchor currency has resulted in an appreciation of the home currency and deterioration of its external trade that is perceived as unsustainable by market participants. This may have been the case for example in the South-Asian crisis in 1997, for the USD had been strongly appreciating versus the JPY since mid-1995. The situation was similar when Argentina abandoned its currency board at the end of 2001, after the USD had been appreciating against the EUR.

Secondly, countries may also choose to loosen their pegs deliberately, as there is not much incentive to peg to a strong currency. Greater flexibility in their exchange rate can restore their competitiveness and sustain their exports. Countries may also be led to this choice by following their neighbors' strategies. In these cases, the slackening of the peg is the result of a voluntary policy choice. This is typical of the present situation, as more and more countries have adopted intermediate regimes, in which they can monitor their parity more loosely, leaving less room to market speculation.

Consequently, we state the hypothesis that currencies linked to the USD are more likely to loosen their peg when the USD is appreciating, while sticking to it otherwise. To check for this hypothesis, we rely on a nonlinear, smooth-transition regression (STR) model applied to a sample of 28 emerging currencies from Asia, Latin America and Middle East over the 19942011 period. The estimated equation links each country's REER change to that of the USDtaking into account the country's fundamentals such as GDP per capita growth and current account as control variables - and uses the change in the USD REER as a transition variable to capture nonlinearities. We show that the REERs of most of these currencies tend to comove with that of the USD when the USD depreciates. This positive relationship is reversed for a number of countries when the USD appreciates over a certain threshold.

The rest of the paper is organized as follows. Section 2 surveys the literature on exits from pegs and provides some insights on the role of the anchor currency. Section 3 is devoted to the empirical analysis, and presents the methodology as well as data and estimation results. Section 4 concludes. 


\section{RUPTURES OF PEGS AND THE ROLE OF THE ANCHOR CURRENCY}

Choosing an exchange rate regime implies to consider two questions: the trade-off between fixed and floating exchange rates, with all the possibilities of intermediate arrangements, as well as the choice of an anchor currency in the case of pegs. As well, exits from pegs may stem from the anchor currency.

\subsection{Exits from pegged exchange rates}

Obstfeld and Rogoff (1995) argued that most pegs are short-lived, their duration being lower than five years on average. The successive falls of the fixed exchange rates in East Asia (1997), Russia (1998), Brazil (1999), and Argentina (2002) corroborated their basic assertion. Klein and Marion (1997) confirm this result by evidencing an average duration of pegs of ten months in Latin America. More recently, Husain et al. (2005) find that pegs are more durable for developing countries with little exposure to international capital markets than for emerging countries, while floats last longer in advanced countries. According to Klein and Shambaugh (2008), 44\% of the fixed exchange rates do not last two years, although $30 \%$ of them last more than five years.

Many empirical studies have attempted to analyze the determinants of exits from pegged regimes; they can be grouped in three categories. First, the literature on currency crises has identified a wide range of determinants for ruptures of pegs, which reflect the trade-offs associated with the benefits and costs of ending a peg as well as the ability of the authorities to maintain it. Among those determinants, real exchange rate overvaluation and forex reserves ratios are considered as early indicators for a rupture of peg, along with fundamentals such as unemployment rate, income growth, fiscal deficit or credit ratios (Berg and Patillo, 1999). Structural factors-such as openness ratio, trade concentration, economic size, degree of economic and financial development - may also affect exchange rate regime choice, (Rizzo, 1998; Poirson, 2001; Juhn and Mauro, 2002; von Hagen and Zhou, 2007). Second, recent studies have pointed that exchange rate regimes shifts may also stem from global financial markets. Tsangarides (2012) shows that some countries with pegged currencies have responded to the recent global financial crisis by moving to a more flexible regime. His findings evidence a reduction by almost 20 percent in the number of less flexible exchange rate arrangements during the crisis, whereas this pattern was mostly reversed by the beginning of 2010. Coudert et al. (2011a) also show that stress on global financial markets increases exchange rate flexibility in emerging countries in a nonlinear way. Third, exiting a peg can also result from shifting preferences of policymakers, depending on the relative weight given to sustaining activity or limiting inflation, and on the shocks hitting the economy (Masson, 2001). Although the former studies provide helpful insights on the factors behind exits from pegs, they neglect the role of the anchor currency in such shifts. 


\subsection{Rationales for choosing the USD as an anchor currency and adverse consequences}

Many countries around the world have chosen to peg their currency to the USD. This choice may explain a number of peg exits or at least their timing, as it is at odds with the optimum currency area (OCA) theory (Mundell, 1961). In this approach, countries should peg their currency to that of their main trade partner, if their business cycles are highly correlated. In reality, the US although the world's largest economy is far from being the main partner of every country with a pegged exchange rate in the world. Therefore, other factors must be at stake in the choice of the anchor currency. We list two of these factors below and then turn to their adverse consequences.

First, the currency structure of the foreign debt plays a role. Countries are incited to peg to the currency in which they are indebted, in order to stabilize their debt burden. Indeed, exchange rate fluctuations can trigger detrimental effects if the domestic agents' balance sheets are currency-mismatched. This reason may seem irrelevant if we think that agents can hedge against currency fluctuations on derivative markets. In reality, it is not irrelevant because, although forex derivative markets do exist in most emerging countries, hedging is very costly. As noticed by Slavov (2003), if hedging was available at low cost, emerging sovereigns would not need to borrow in foreign currencies for investors themselves would agree to buy local currency debt and hedge themselves against currency fluctuations. So the "original sin" (the inability to borrow in domestic currency) is due to the incompleteness of financial markets and high costs of hedging. As most emerging countries borrow in USD, pegging against the USD is rationale in order to minimize the costs of market incompleteness.

Second, network externalities create an incentive for all countries to peg to the same dominant currency. Bid-ask spreads on the forex markets are much smaller for highly traded currencies such as the USD (BIS, 2010), which mitigates the cost of forex interventions. Moreover, by pegging to the same dominant currency, countries in the same area may attempt to stabilize their exchange rates relative to their trade partners. Regarding network externalities, the key position of the USD has been inherited from the Bretton Woods system and always been maintained since then (Bracke and Bunda, 2011).

The previous reasons explain why the dollar is predominant among the anchor currencies. Though understandable, this situation is highly problematic for very few-if no-emerging countries can claim to form an OCA with the US. Therefore, pegging to the USD implies that the country's effective exchange rate (EER) is forced to mimic the behaviour of that of the USD. The country's EER would be stabilized only if the US were its only trade partner and also its only competitor in third markets, which is obviously hardly the case.

Consequently, currencies with USD pegged exchange rates are submitted to the wild fluctuations of the USD. They reap a competitive advantage in periods when the USD depreciates towards other currencies. Conversely, they can be badly affected in times of USD appreciation, because their own REER appreciates in the same way, as long as their inflation rate is no smaller than that of the US. Indeed as soon as the USD significantly appreciates, overvaluation — or at least loss of competitiveness - is looming for the currencies pegged to 
the USD. This has been already evidenced for pegged commodity and oil currencies by Coudert et al. (2011b), who showed that misalignments in these currencies closely co-move with those of their anchor currency, either USD or EUR. Moreover, a straightforward observation shows that some disastrous crises of USD pegged currencies occurred just after a sharp USD appreciation. For example, the "Asian crisis" in 1997 followed a striking appreciation of the USD towards the JPY ( $+50 \%$ from April 1995 until April 1997). The collapse of Argentina's currency board happened just after the USD appreciated by $30 \%$ against the EUR (from January 1999 to December 2001); the effect was detrimental on Argentina's REER, as Spain is one of its main trade partners. On the whole, on the top of all the usual reasons mentioned in Section 2.1 for ruptures of pegs, the appreciation of the anchor currency may also play a key role and should be closely investigated.

\section{EMPIRICAL ANALYSIS}

\subsection{Methodology}

In order to investigate whether countries adapt their currency regime according to fluctuations of the anchor currency, we rely on nonlinear, smooth transition regression (STR) models. These processes allow us to model the relationship between the changes in the exchange rate of a given country and the USD, according to the changes in the US currency: the nature of the relationship between the two currencies depends on the evolution-appreciation or depreciation - of the USD. STR models are thus particularly useful to investigate whether countries tend to loosen their peg to the USD in times of dollar appreciation.

Our STR specification is given by: ${ }^{2}$

$$
\begin{aligned}
& \Delta \text { LREER }_{t}=\alpha_{10}+\sum_{j=1}^{p_{11}} \alpha_{1 j} \Delta \text { LREER }_{t-j}+\sum_{j=1}^{p_{12}} \alpha_{2 j} \Delta \text { LPROD }_{t-j}+\sum_{j=1}^{p_{13}} \alpha_{3 j} B C_{t-j} \\
& +\sum_{j=1}^{p_{14}} \alpha_{4 j} \Delta \text { LREERUS }_{t-j}+\left(\alpha_{20}+\sum_{j=1}^{p_{24}} \beta_{4 j} \Delta \text { LREERUS }_{t-j}\right) g\left(\Delta \text { LREERUS }_{t} ; \gamma, c\right)+\varepsilon_{t}
\end{aligned}
$$

where $\varepsilon_{t}$ is iid $\left(0, \sigma_{\varepsilon}^{2}\right)$, LREER is the real effective exchange rate of a given country expressed in logarithm, LREERUS is the USD real effective exchange rate (in logarithm), LPROD denotes a proxy for relative productivity (in logarithm), BC is the current balance expressed as a percentage of GDP. Exchange rate and productivity variables being non stationary, ${ }^{3}$ they are taken in first difference. $\triangle L R E E R U S$ acts as the transition variable and $g\left(\triangle L R E E R U S_{t} ; \gamma, c\right)$ is the transition function which

\footnotetext{
${ }^{2}$ For simplifying purposes, we consider a specification in which only the impact of the US real effective exchange rate is regime dependent.

${ }^{3}$ Results of unit root tests are available upon request to the authors.
} 
by convention is bounded by zero and one. $\gamma>0$ denotes the slope parameter that determines the smoothness of the transition from one regime to the other (i.e. the abruptness of the transition dynamics at $\mathrm{c}$ ), and $\mathrm{c}$ is the threshold parameter.

The dynamics of the real effective exchange rate is governed by two regimes-linear and nonlinear-depending on the evolution of the USD real effective exchange rate. The transition from one regime to the other is smooth, and the transition functions commonly considered are given by (Teräsvirta and Anderson, 1992):

$g\left(\Delta\right.$ LREERUS $\left._{t} ; \gamma, c\right)=\left(1+\exp \left(-\gamma\left(\Delta \text { LREERUS }_{t}-c\right)\right)\right)^{-1}:$ logistic STR model (LSTR)

$g\left(\Delta\right.$ REERUS $\left._{t} ; \gamma, c\right)=1-\exp \left(-\gamma\left(\Delta \text { LREERUS }_{t}-c\right)^{2}\right):$ exponential STR model (ESTR)

The LSTR specification accounts for asymmetric realizations, in the sense that the two regimes are associated with small and large values of the transition variable relative to the threshold value. On the other hand, in the ESTR model, increases and reductions in the transition variable have similar effects, but the middle grounds are characterized by different dynamics. In both cases - LSTR and ESTR — when $\gamma$ goes to zero, the STR process reduces to a linear model. When $\gamma$ tends to infinity, the LSTR model becomes a two-regime threshold model with abrupt transition (Tong, 1990). This is not the case for the ESTR model which also becomes linear when the slope parameter $\gamma$ goes to infinity. To recover the threshold model as a special case of the ESTR specification, we follow Jansen and Teräsvirta (1996) by writing the ESTR model such as:

$g\left(\Delta \operatorname{LREERUS}_{t} ; \gamma, c\right)=\left(1+\exp \left(-\gamma\left(\Delta \text { LREERUS }_{t}-c_{1}\right)\left(\Delta \text { LREERUS }_{t}-c_{2}\right)\right)\right)^{-1}$

with $c_{1} \leq c_{2}$ and $c=\left(c_{1}, c_{2}\right)^{\prime}$. When $\gamma$ goes to infinity and if $c_{1} \neq c_{2}$, we have: $g\left(\triangle\right.$ LREERUS $\left._{t} ; \gamma, c\right)=1$ for $\triangle$ LREERUS $_{t}<c_{1}$ and $\triangle$ LREERUS $_{t}>c_{2}$, and $g\left(\triangle L R E E R U S_{t} ; \gamma, c\right)=0$ for $c_{1} \leq \Delta L R E E R U S_{t} \leq c_{2}$. In this case, the ESTR model with Equation (2) as the transition function allows recovering a three-regime threshold model with abrupt transition as a special case — the two extreme regimes being similar.

For currencies pegged to the USD, it is expected to find a positive relationship between the change in the considered country's exchange rate and the dollar. If, however, those countries tend to loosen their peg in times of dollar appreciation, we would expect to find a negative, or non significant, relationship between both variables in the nonlinear regime. In other words, $\alpha_{4}$ are expected to be positive, while $\left(\alpha_{4}+\beta_{4}\right)$ are expected to be negative or non significant.

To specify the STR model, we follow the methodology proposed by Teräsvirta (1994). We first test for linearity and, if the null hypothesis is rejected, choose between the LSTR and ESTR specifications using the sequential strategy developed by Teräsvirta (1994). Once this 
choice has been made, we estimate the STR model and apply various misspecification tests: test of no residual autocorrelation (Teräsvirta, 1998), LM-test of no remaining nonlinearity (Eitrheim and Teräsvirta, 1996), and ARCH-LM test (Engle, 1982).

\subsection{Data and stylized facts}

We consider a sample of 28 emerging currencies, listed in Table 1, over the period from 1994Q1 to 2011Q3 at a quarterly frequency. This set of currencies matches the main emerging countries in the traditional dollar zones of influence, which are Asia, Latin America and the Middle East: they are — or have been-more or less linked to the USD over the period under study, at least for some time (see infra).

\section{Table 1. List of the currencies}

\begin{tabular}{lll}
\hline Asia & Latin America & Middle East and others \\
\hline Chinese renminbi (CNY) & Argentine peso (ARS) & $\begin{array}{l}\text { United Arab Emirates dirham } \\
\text { (AED) }\end{array}$ \\
Hong Kong dollar (HKD) & Bolivian boliviano (BOB) & Bahrain dinar (BHD) \\
Indonesian rupiah (IDR) & Brazil real (BRL) & Iranian rial (IRR) \\
Indian rupee (INR) & Chilean peso (CLP) & Pakistani rupee (PKR) \\
Korean won (KRW) & Colombian peso (COP) & Saudi riyal (SAR) \\
Malaysian ringgit (MYR) & Costa Rican colon (CRC)* & South African rand (ZAR) \\
Philippine peso (PHP) & Dominican peso (DOP) & \\
Singapore dollar (SGD) & Mexican peso (MXN) & \\
Thailand baht (THB) & Peruvian new sol (PEN) & \\
& Paraguayan guarani (PYG) & \\
& Trinidad and Tobago dollar (TTD)* & \\
& Uruguayan peso (UYU) & \\
& Venezuelan bolivar (VEF) & \\
$*:$ the sample period starts in 2000Q1 for these two countries.
\end{tabular}

Turning to the series, real effective exchange rates are extracted from International Financial Statistics (IMF), except for Hong Kong, India, Indonesia, Korea, Peru, Thailand and United Arab Emirates which are taken from the Bank of International Settlements. The current account balance series is expressed as percentage of GDP and taken from WEO (IMF). We rely on the purchasing power parity (PPP) per capita GDP, also extracted from WEO, as a proxy for relative productivity. All series but the current account balances are expressed in logarithms and are first-differentiated.

To provide a first insight regarding the links between countries' real effective exchange rates and the USD, Figure 1 displays the evolution of both series for some countries. ${ }^{4}$ The gray bands represent the main periods of dollar appreciation. For many countries, the existence of a reverse relationship between the two exchange rates series in times of dollar appreciation is

\footnotetext{
${ }^{4}$ To avoid too many figures, we report the graphs only for some countries. Figures for all countries are available upon request to the authors.
} 
not obvious. Regarding Middle East countries, while Bahrain and Saudi Arabia closely follow the evolution of the USD, United Arab Emirates and Iran display an appreciating trend over the whole period, independently of the evolution of the USD. In other words, Middle East countries do not seem to loosen their peg in times of dollar appreciation; this is not surprising as their exports, mainly formed of oil, do not directly depend on competitiveness issues. This global picture is also observed for other economies, such as China, Uruguay and Venezuelathe latter being also oil exporter. For many countries, peg breaks may appear at some times when the USD appreciates, but not systematically. Some occasional peg abandons could indeed be observed for Latin American countries (Brazil, Chile for instance), and especially for Asian currencies (India, Korea, Thailand). The two countries for which peg losing in periods of dollar appreciation are the most marked are Indonesia and South Africa. On the whole, anchor breaks are more likely to be irregular than systematic.

Figure 1. Real effective exchange rates, in logarithm

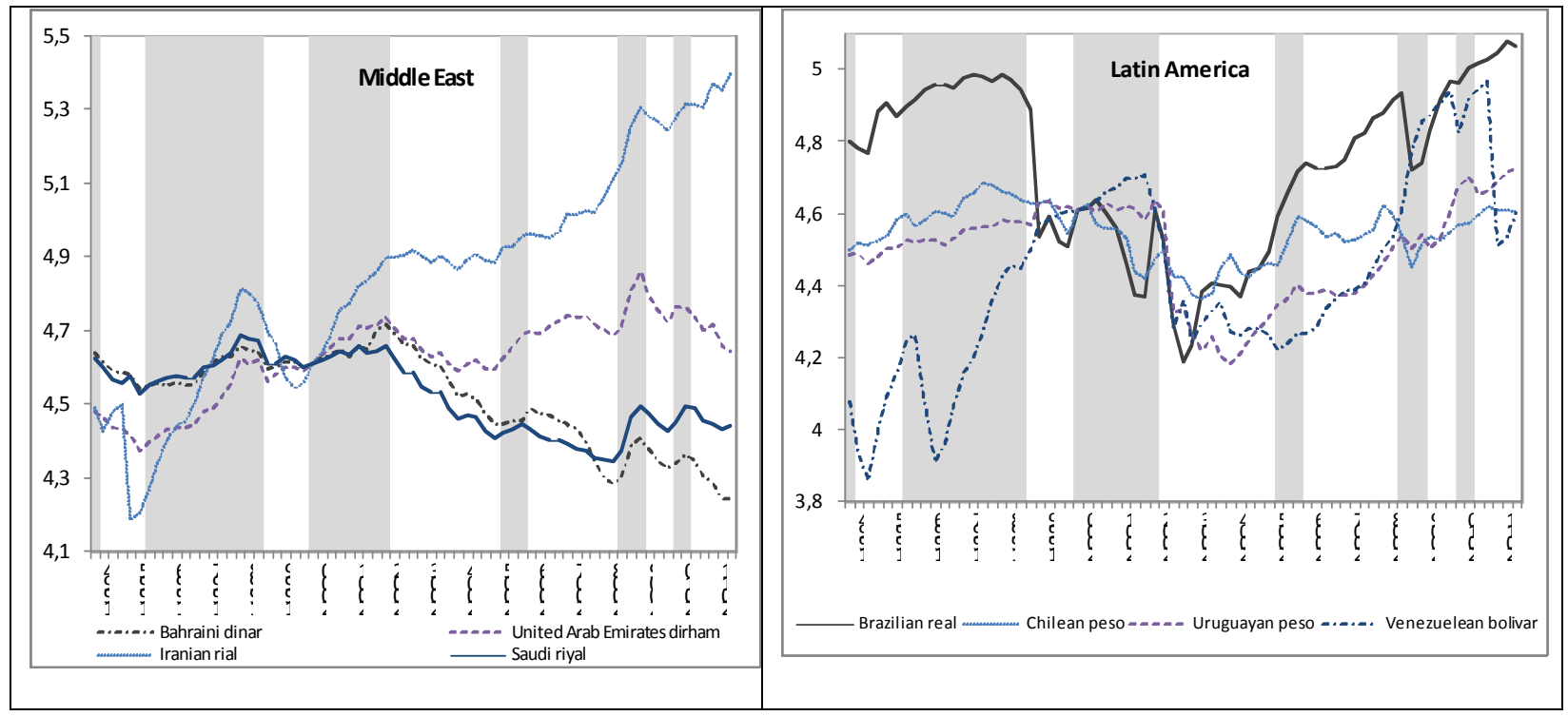



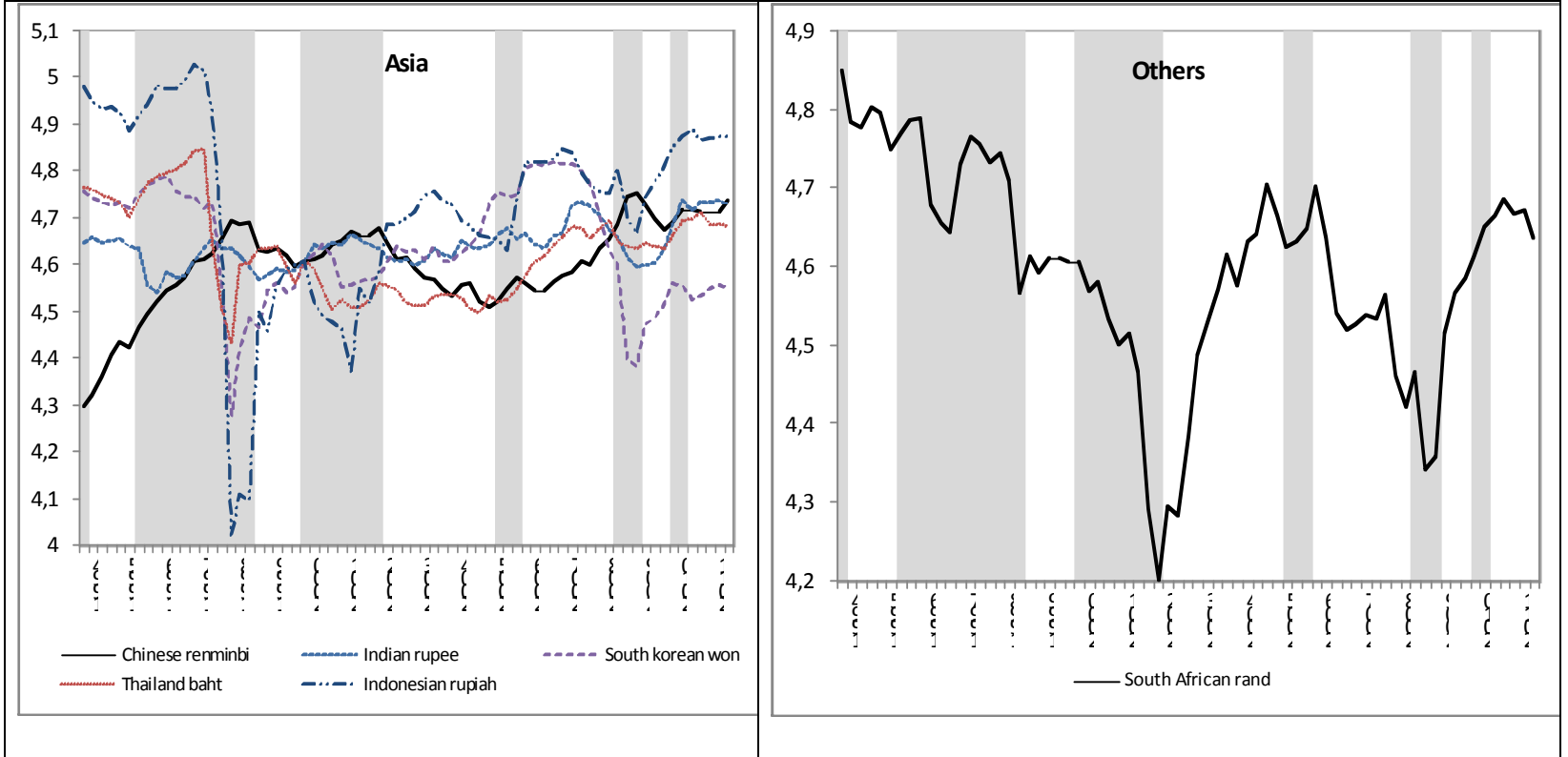

Note: The gray areas represent periods of appreciation of the dollar real effective exchange rate. Sources: IMF, BIS.

\subsection{Country-by-country estimations}

Table 2 reports the results from the estimation of STR models for each considered country, together with the conclusion issued from the linearity test. ${ }^{5}$ For the sake of brevity, we only report the coefficients relating to our variables of interest, namely the coefficient associated with the US real effective exchange rate in both linear and nonlinear regimes, as well as the estimated values of the slope and threshold parameters. For all countries, the number of lags selected using information criteria is equal to 1, i.e. $p_{14}=p_{24}=1$.

\footnotetext{
${ }^{5}$ Table A1 in Appendix reports the results of misspecification tests. Globally, the residual series generally have the good properties, showing no autocorrelation, no remaining nonlinearity and no ARCH effect.
} 
Table 2. Country-by-country estimations of STR models

\begin{tabular}{|c|c|c|c|c|c|c|}
\hline Currency & Model & $\begin{array}{l}\text { Linear } \\
\alpha 4\end{array}$ & $\begin{array}{l}\text { Nonlinear } \\
\alpha 4+\beta 4\end{array}$ & $\gamma$ & $\mathrm{c} 1$ & $\mathrm{c} 2$ \\
\hline \multicolumn{7}{|l|}{ Asia } \\
\hline CNY & LSTR & 0.9809* & 0.5993 & 0.9388 & -0.0394 & \\
\hline HKD & LSTR & $1.1781 * *$ & 0.9355 & 242.0856 & -0.0231 & \\
\hline IDR & LSTR & 0.7301* & $-5.9701 * *$ & 15.6466 & 0.0268 & \\
\hline INR & LSTR & -4.4562 & -0.1049 & 3.6229 & -0.0489 & \\
\hline$K R W$ & LSTR & 0.0434 & $-5.4658 * *$ & 1834.44 & 0.0293 & \\
\hline MYR & LSTR & $0.3853 * * *$ & $-2.2491 * *$ & 145.9492 & 0.0281 & \\
\hline PHP & Linear & -0.0249 & & & & \\
\hline SGD & Linear & -0.0428 & & & & \\
\hline THB & ESTR & $2.4860 * * *$ & $-0.1655^{* * *}$ & 4562.3319 & $\mathbf{0 . 0 0 0 0 5}$ & 0.0049 \\
\hline \multicolumn{7}{|c|}{ Latin America } \\
\hline ARS & Linear & -0.1130 & & & & \\
\hline BOB & LSTR & $0.8204 * * *$ & $-0.2953^{* *}$ & 617.0836 & 0.0287 & \\
\hline$B R L$ & ESTR & -0.2276 & $-2.8414 * * *$ & 47.8469 & -0.0205 & 0.0896 \\
\hline CLP & Linear & 0.0469 & & & & \\
\hline $\mathrm{COP}$ & Linear & -0.3253 & & & & \\
\hline CRC & ESTR & $0.6346 * * *$ & 6.2071 & 6.3647 & -0.0408 & 0.0339 \\
\hline$D O P$ & ESTR & 0.0792 & $-1.9926 * * *$ & 37.5322 & -0.0196 & 0.1199 \\
\hline$M X N$ & LSTR & 0.0138 & $-1.7190 * *$ & 1002.7056 & 0.0219 & \\
\hline PEN & Linear & 0.1280 & & & & \\
\hline PYG & Linear & $-0.6078 * * *$ & & & & \\
\hline TTD & Linear & -0.0499 & & & & \\
\hline URU & Linear & $-0.3969^{*}$ & & & & \\
\hline VEF & Linear & 0.2490 & & & & \\
\hline \multicolumn{7}{|c|}{ Middle East and others } \\
\hline AED & Linear & $0.2539 *$ & & & & \\
\hline BHD & Linear & 0.2835 & & & & \\
\hline IRR & LSTR & $0.7741 * * *$ & 1.2475 & 2741.3122 & 0.0132 & \\
\hline PKR & Linear & -0.0249 & & & & \\
\hline SAR & Linear & -0.0577 & & & & \\
\hline ZAR & LSTR & 0.9921* & $-1.1112 * * *$ & 232.7781 & -0.0114 & \\
\hline
\end{tabular}

$*$ (resp. $\left.{ }^{* *}, * * *\right)$ : significant at the $10 \%$ (resp. 5\%, 1\%) statistical level. In bold: countries for which $\alpha_{4}>0$ and either $\alpha_{4}+\beta_{4}<0$ or $\alpha_{4}+\beta_{4}$ non significant. In italics: countries for which $\alpha_{4}$ is non significant and $\alpha_{4}+\beta_{4}<0$.

Results in Table 2 globally confirm the graphical analysis. First, the group of Middle East economies is characterized in most cases by a linear relationship between the corresponding countries' real effective exchange rates and the USD, meaning that there is no peg break. This feature can be rationalized in the case of oil-exporting countries. As the oil price is set at a world level, the domestic exchange rate does not matter in external competitiveness of those countries (it is only relevant for internal competitiveness, determining the relative profitability 
of the oil sector). Regarding Iran, its currency tends to appreciate even in times of dollar appreciation, a fact that is confirmed by the growing trend of the Iranian real effective exchange rate all over the period under study (see Figure 1). Confirming the graphical analysis, the South African currency clearly tends to loosen its peg to the USD when the latter appreciates: while the two currencies evolve in the same direction when the dollar depreciates (up until a threshold of 1.14\%), the relationship reverses when the dollar tends to appreciate. This result is not surprising with regard to the initiative of the South African government to promote export-oriented growth in the country through the attraction of local and foreign investors. In order to give impetus to export-led growth - which is the aim of the Industrial Development Zone program-South Africa is encouraged to maintain its competitiveness and, consequently, to limit the appreciation of the home currency by untying its peg in times of dollar appreciation.

Second, for Latin American countries, the relationship between the two real effective exchange rates is negative for Brazil, Dominican Republic and Mexico in the nonlinear regime. While the Mexican currency and the USD are not closely linked in the linear regime, they evolve in the opposite direction when the dollar tends to appreciate beyond $2.2 \%$. Turning to the Brazilian real, it is inversely linked to the USD when the latter evolves in the range $[-2.05 \%, 8.96 \%]$, confirming that Brazil tends to loosen its peg when the dollar appreciates. These findings regarding Mexico and, to a lesser extent, Brazil may also be linked to the increasing export-oriented growth strategy of those economies. In particular, the NAFTA having considerably increased the export dynamism of Mexico, this country tends to untie its peg to the US currency in times of dollar appreciation to sustain its exports and restore its competitiveness.

Finally, for most of the Asian countries, a nonlinear relationship is obtained. More specifically, our findings show that, while being positively linked in depreciation and weak appreciation times, Indonesia and Malaysia tend to loosen their peg when the USD appreciates beyond 2.7-2.8\% per quarter: when this threshold is crossed, the currencies evolve in the opposite direction. For China and Hong Kong, they stop to follow the evolution of the USD when the latter tends to appreciate beyond -3.94 and $-2.31 \%$ respectively. On the whole, our findings put forward that anchor breaks are mostly observed for Asian currencies in times of dollar appreciation. This result may be explained by the fact that Asian economies are typically export-oriented growth countries, with exports that are not mainly oriented towards the United States. Consequently, to maintain their export competitiveness, Asian countries are likely to untie their peg to the USD to limit or enhance the appreciation of their home currency and therefore their REER.

\subsection{Panel estimations}

To further check our findings and provide more synthetic results, we also run all the estimations in a panel data framework by considering various groups of countries. To this end, we rely on the panel smooth transition regression (PSTR) model introduced by González et al. (2005), which involves three steps. In the first, specification step, we test for 
homogeneity against the PSTR alternative, using the LM-test statistic provided by González et al. (2005). In the second, estimation step, nonlinear least squares are used to obtain the parameter estimates, once the data have been demeaned. Finally, in the evaluation step, we apply misspecification tests in order to check the validity of the estimated PSTR model.

We first classify our countries into four groups, according to a geographical criterion: the complete panel includes all the 28 currencies in the sample, whereas the three others group together the countries belonging to the same geographic area (Asia, Latin America, and Middle East). Results reported in Table 3 confirm those issued from the country-by-country analysis. Indeed, they show that while Asian currencies co-move with the USD when the latter depreciates or slowly appreciates, they tend to loosen their peg when the US currency appreciates beyond $2.76 \%$. Regarding the two other subgroups of countries, the null hypothesis of linearity is not rejected.

Table 3. Results of PSTR estimation (geographical classification)

\begin{tabular}{|c|c|c|c|c|}
\hline Panel & $\begin{array}{l}\text { Linear } \\
\alpha 4\end{array}$ & $\begin{array}{l}\text { Nonlinear } \\
\alpha 4+\beta 4\end{array}$ & $\gamma$ & $\mathrm{C}$ \\
\hline Whole sample & $0.2525 * * *$ & $-0.3611 * * *$ & 6090 & 0.0294 \\
\hline Asia & $0.2436^{* * *}$ & $-0.4813 * *$ & 612.5239 & 0.0276 \\
\hline Latin America & Linear & & & \\
\hline Middle East & Linear & & & \\
\hline
\end{tabular}

We also consider a second classification based on exchange-rate arrangements. To this end, we rely on the IMF classification for the year $2010{ }^{6}$, and classify the countries according to three groups. The characteristics of the exchange-rate regimes, together with the corresponding countries are displayed in Table 4.

\footnotetext{
${ }^{6}$ See the IMF official classification on: http://personal.lse.ac.uk/ilzetzki/IRRBack.htm.
} 
Table 4. Exchange-rate regimes (in 2010) and corresponding currencies

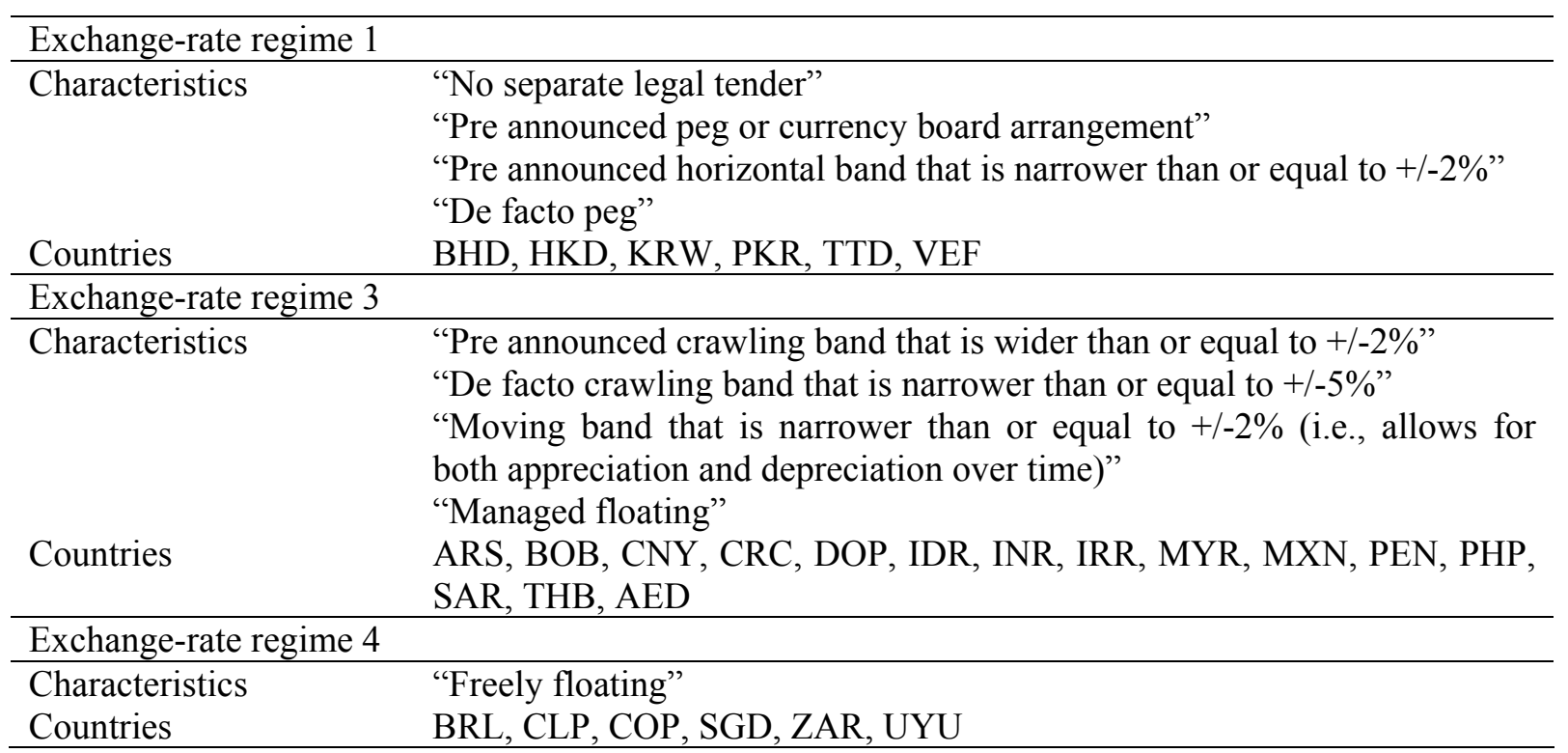

Note: the exchange-rate classification and the corresponding characteristics are taken from IMF.

This second classification allows us to investigate whether the nature of the exchange-rate arrangement impacts the relationship between countries' real effective exchange rates and that of the USD. We should expect that countries which are strongly anchored to the USD may be more dependent on the evolution of the US currency than economies which tend to adopt a free floating system. More specifically, it seems reasonable to think that currencies characterized by arrangements of types 1 and - to a lesser extent-3 will tend to be more sensitive to the evolution of the USD than those belonging to the group 4.

On the whole, results displayed in Table 5 confirm this hypothesis. Indeed, for the exchangerate regime 4 , the null hypothesis of linearity is not rejected. ${ }^{7}$ This result seems relevant given that it concerns countries that have adopted a free floating exchange-rate regime in 2010. Turning to the other exchange-rate arrangements, we find that countries' real effective exchanges rates and the USD are positively linked in the linear regime, particularly strongly in the case of the exchange-rate regime 1. This is not surprising given that regime 1 classification corresponds to the case where the peg to the USD is the most marked. When the USD appreciation goes beyond 4\%, the relationship between both exchange rates series becomes non significant, meaning that the considered countries tend to loosen their peg. In the case of the exchange-rate arrangement 3, an anchor break appears for USD appreciations higher than $5.23 \%$ by quarter, as the relationship between both currencies turns negative. The

\footnotetext{
${ }^{7}$ In addition, the estimated coefficient in the linear model was found to be non significant, confirming the fact that currencies belonging to group 4 are not sensitive to USD fluctuations.
} 
findings for both panel decompositions - geographical and according to the exchange-rate arrangement - are consistent given that most of the Asian countries belong to the exchangerate regime 3.

Table 5. Results of PSTR estimation (exchange-rate regime classification)

\begin{tabular}{lllll}
\hline Panel & $\begin{array}{l}\text { Linear } \\
\alpha 4\end{array}$ & $\begin{array}{l}\text { Nonlinear } \\
\alpha 4+\beta 4\end{array}$ & $\gamma$ & $\mathrm{C}$ \\
\hline Whole sample & $0.2525^{* * *}$ & $-0.3611^{* * *}$ & 6090 & 0.0294 \\
ER regime 1 & $0.5045^{* * *}$ & 0.1559 & 175.1788 & 0.0405 \\
ER regime 3 & $\begin{array}{l}0.2013^{*} \\
\text { ER regime 4 }\end{array}$ & $-0.3482^{*}$ & 115.4846 & 0.0523 \\
\hline$*\left(\right.$ lesp. ${ }^{* *}, * *$ ) & significant at the 10\% (resp. 5\%, 1\%) statistical level. &
\end{tabular}

\section{CONCLUSION}

In this paper, we analyse the reasons for ruptures of exchange rate pegs from a new standpoint. Although the previous literature has focused either on domestic reasons or on global financial market environment, we emphasize the role played by the fluctuations in the anchor currency. As most countries whose currencies are pegged to the USD have many other important trade partners, their effective exchange rate is not stabilized by the peg; on the contrary, it tends to mimic the fluctuations of the USD. This USD anchorage is at odds with the optimum currency area theory and raises a number of problems. Indeed, pegging a currency nowadays is generally aimed at stabilizing external competitiveness for sustaining an export-led growth. Unfortunately, this aim can be attained only during periods of USD stability or depreciation.

As soon as the USD appreciates, USD pegged currencies are affected by a loss of competitiveness towards their other trade partners. Above a certain threshold, this loss of competitiveness becomes challenging for the domestic economy and governments may be incited either to loosen their pegs or be pushed to do it under market pressures. We test for this hypothesis on a sample of 28 emerging currencies from Asia, Latin America and the Middle East using smooth transition regression models to evidence these nonlinear effects of the USD movements on emerging currencies. A number of currencies are shown to be positively linked to the USD as long as the USD does not appreciate too much, but switch to a more flexible regime as soon as the USD appreciation exceeds a given threshold. We show that these nonlinear effects are especially at stake in Asia where growth is export-oriented, while mitigated in Latin America, and inexistent in the Middle East as external competitiveness is not a matter of importance for selling oil exports. 


\section{REFERENCES}

Alesina, A., Wagner, A., 2006, "Choosing (and reneging on) exchange rate regimes", Journal of the European Economic Association 4(4), 770-799.

Baxter, M., Stockman, A.C.,, 1989, "Business cycles and the exchange-rate regime: some international evidence", Journal of Monetary Economics 23(3), 377-400.

Berg, A and Pattillo, C., 1999, "Are Currency Crises Predictable? A Test”, IMF Staff Papers 46(2), Palgrave Macmillan.

BIS, 2010, Triennial Central Bank Survey of Foreign Exchange and Derivatives Market Activity in September.

Bracke, T., Bunda, I., 2011, "Exchange rate anchoring: is there still a de facto US dollar standard?", ECB Working Paper n ${ }^{\circ} 1353$, June, 1-38.

Calvo, G.A., Reinhart, C.M., 2002, "Fear of floating”, Quarterly Journal of Economics 117, 379-408.

Coudert, V., Couharde C., Mignon V., 2011a, "Exchange rate volatility across financial crises", Journal of Banking and Finance 35, 3010-3018.

Coudert, V., Couharde, C., Mignon, V., 2011b, "Does Euro or Dollar Pegging Impact the Real Exchange Rate? The Case of Oil and Commodity Currencies", World Economy 34(9), 1557-1592.

Coudert, V., Mignon, V., 2012, "The 'Forward Premium Puzzle' and the Sovereign Default risk", Journal of International Money and Finance, forthcoming.

Eitrheim, O., Teräsvirta, T., 1996, "Testing the adequacy of smooth transition autoregressive models", Journal of Econometrics 74, 59-76.

Engle, R.F., 1982, "Autoregressive conditional heteroscedasticity with estimates of the variance of United Kingdom inflation”, Econometrica 50, 987-1007.

Flood, R., Rose, A., 1995, "Fixing exchange rates: a virtual quest for fundamentals", Journal of Monetary Economics XXXVI, 3-37.

Frankel, J., 1999, "No single currency regime is right for all countries or at all times", NBER Working Paper 7338, September.

González, A., Teräsvirta, T., van Dijk, D., 2005, "Panel Smooth Transition regression models", Research Paper 165, Quantitative Finance Research Centre, University of Technology, Sidney.

von Hagen, J., Zhou, J., 2007, "The choice of exchange rate regimes in developing countries: A multinomial panel analysis", Journal of International Money and Finance 26, 1071-1094.

Husain, A.M., Mody A., Rogoff, K.S., 2005, "Exchange rate regime durability and performance in developing versus advanced economies", Journal of Monetary Economics 52, 35-64.

Jansen, E.S., Teräsvirta, T., 1996, "Testing parameter constancy and super-exogeneity in econometric equations", Oxford Bulletin of Economics and Statistics 58, 735-768.

Juhn, G., Mauro, P., 2002, "Long-run determinants of exchange rate regimes: A simple sensitivity analysis”, IMF Working Papers WP/02/104 International Monetary Fund, Washington D.C.

Klein, M., Marion N., 1997, "Explaining the duration of exchange rate pegs", Journal of Development Economics 54, 387-404. 
Klein, M. W., Shambaugh, J. C., 2008, "The dynamics of exchange rate regimes: Fixes, floats, and flips", Journal of International Economics 75, 70-92.

Kwack, S. Y, 2004, "An optimum currency area in East Asia: feasibility, coordination, and leadership role", Journal of Asian Economics 15(1), 153-169.

Masson, P. R., 2001, "Exchange rate regime transitions", Journal of Development Economics 64 (2), $571-586$

McKinnon, R., 2000, “The East Asian dollar standard: Life after death?”, Economic Notes 29, 31-82.

Mundell, R., 1961, “A theory of optimal currency areas”, American Economic Review 51, 657-665.

Obstfeld, M., Rogoff, K., 1995, "The mirage of fixed exchange rates", Journal of Economic Perspectives 9, 73-96.

Poirson, H., 2001, "How do countries choose their exchange rate regime?", IMF Working Paper WP/01/46, International Monetary Fund, Washington D.C.

Rizzo, J. M., 1998, "The economic determinants of the choice of an exchange rate regime: A probit analysis", Economics Letters 59, 283-287.

Slavov, S., 2003, "But can't they hedge? Managing foreign exchange risk under original sin", Working paper 177, Stanford Center for International Development.

Teräsvirta, T., 1994, "Specification, estimation, and evaluation of smooth transition autoregressive models", Journal of the American Statistical Association 89, 208-218.

Teräsvirta, T., 1998, "Modeling economic relationships with smooth transition regressions", in: Ullah, A., Giles, D. (Eds.), Handbook of Applied Economic Statistics, Dekker, New York.

Teräsvirta, T., Anderson, H.M., 1992, "Characterizing nonlinearities in business cycles using smooth transition autoregressive models", Journal of Applied Econometrics 7(S), S119-36.

Tong, H., 1990, Non-linear Time Series. A Dynamical System Approach, Oxford University Press, Oxford.

Tsangarides, C., 2012, "Crisis and Recovery: Role of the Exchange Rate Regime in Emerging Market Countries", Journal of Macroeconomics 34, 470-488. 


\section{APPENDiX}

Table A1. Misspecification tests (p-values)

\begin{tabular}{|c|c|c|c|}
\hline Currency & No autocorrelation & $\begin{array}{l}\text { No remaining } \\
\text { nonlinearity }\end{array}$ & $\mathrm{ARCH}$ \\
\hline \multicolumn{4}{|l|}{ Asia } \\
\hline $\mathrm{CNY}$ & 0.27 & 0.33 & 0.83 \\
\hline HKD & 0.40 & 0.62 & 0.74 \\
\hline IDR & 0.83 & 0.41 & 0.43 \\
\hline INR & 0.58 & 0.57 & 0.43 \\
\hline KRW & 0.34 & 0.40 & 0.99 \\
\hline MYR & 0.74 & 0.61 & 0.82 \\
\hline THB & 0.18 & 0.83 & 0.71 \\
\hline \multicolumn{4}{|c|}{ Latin America } \\
\hline $\mathrm{BOB}$ & 0.15 & 0.13 & 0.36 \\
\hline BRL & 0.60 & 0.17 & 0.97 \\
\hline CRC & 0.75 & 0.48 & 0.06 \\
\hline DOP & 0.46 & 0.95 & 0.03 \\
\hline MXN & 0.22 & 0.02 & 0.46 \\
\hline \multicolumn{4}{|c|}{ Middle East and others } \\
\hline IRR & 0.62 & 0.49 & 0.88 \\
\hline ZAR & 0.39 & 0.52 & 0.93 \\
\hline
\end{tabular}

Note: This table presents the results of residual tests (p-values). No autocorrelation refers to the test of no residual autocorrelation of order 1 described in Teräsvirta (1998). No remaining nonlinearity is the LM-test of no additive nonlinearity developed by Eitrheim and Teräsvirta (1996). ARCH is the ARCH-LM test of homoskedasticity against the alternative of conditional heteroskedasticity (Engle, 1982). 


\section{LIST OF WORKING PAPERS RELEASED BY CEPII}

An Exhaustive list is available on the website: \|www.cepii.fr.

No

2012-20 On the links between stock and commodity markets volatility

2012-19 European Export Performance, Angela Cheptea

2012-18 The Few Leading the Many: Foreign Affiliates and Business Cycle Comovement

2012-17 Native Language, Spoken Language, Translation and Trade

2012-16 Assessing the Price-Raising Effect of Non-Tariff Measures in Africa

2012-15 International Migration and Trade Agreements: the New Role of PTAs

2012-14 Scanning the Ups and Downs of China's Trade Imbalances

2012-13 Revisiting the Theory of Optimum Currency Areas: Is the CFA Franc Zone Sustainable?

2012-12 Macroeconomic Transmission of Eurozone Shocks to Emerging Economies

2012-11 The fiscal Impact of Immigration in France: a Generational Accounting Approach

2012-10 MAcMap-HS6 2007, an Exhaustive and Consistent Measure of Applied Protection in 2007
Authors

A. Creti, M. Joëts \& V. Mignon

A. Cheptea, L. Fontagné \& S. Zignago

J. Kleinert, J. Martin \& F. Toubal

J. Melitz \& F. Toubal

O.Cadot \& J.Gourdon

G. Orefice

F. Lemoine \& D. Ünal C. Couharde, I. Coulibaly, D. Guerreiro \& V. Mignon

B. Erten

X. Chojnicki

H. Guimbard, S. Jean, M. Mimouni \& X. Pichot 
No

2012-09 Regional Integration and Natural Resources: Who Benefits? Evidence from MENA

2012-08 A Foreign Direct Investment Database for Global CGE Models

2012-07 On Currency Misalignments within the Euro Area

2012-06 How Frequently Firms Export? Evidence from France

2012-05 Fiscal Sustainability in the Presence of Systemic Banks: the Case of EU Countries

2012-04 Low-Wage Countries' Competition, Reallocation across Firms and the Quality Content of Exports

2012-03 The Great Shift: Macroeconomic Projections for the World Economy at the 2050 Horizon

2012-02 The Discriminatory Effect of Domestic Regulations on International Services Trade: Evidence from FirmLevel Data

2012-01 Optimal food price stabilization in a small open developing country

2011-33 Export Dynamics and Sales at Home

2011-32 Entry on Difficult Export Markets by Chinese Domestic Firms: The Role of Foreign Export Spillovers

2011-31 French Firms at the Conquest of Asian Markets: The Role of Export Spillovers

2011-30 Environmental Policy and Trade Performance: Evidence from China
Authors

C. Carrère, J. Gourdon $\&$ M. Olarreaga

C. Gouël, H. Guimbard \& D. Laborde

V. Coudert, C. Couharde \& V. Mignon

G. Békés, L. Fontagné, B. Muraközy \& V. Vicard

A. Bénassy-Quéré \& G. Roussellet

J. Martin \& I. Méjean

J. Fouré, A. Bénassy-Quéré \& L. Fontagné

M. Crozet, E. Milet \& D. Mirza

C. Gouël \& S. Jean

N. Berman, A. Berthou \& J. Héricourt

F. Mayneris \& S. Poncet

F. Mayneris \& S. Poncet L. Hering \& S. Poncet 
2011-29 Immigration, Unemployment and GDP in the Host Country: Bootstrap Panel Granger Causality Analysis on OECD Countries

2011-28 Index Trading and Agricultural Commodity Prices: A Panel Granger Causality Analysis

G. Capelle-Blancard \& D. Coulibaly

B. Carton

2011-27 The Impossible Trinity Revised: An Application to China

2011-26 Isolating the Network Effect of Immigrants on Trade

M. Aleksynska \& G. Peri

2011-25 Notes on CEPII's Distances Measures: The GeoDist Database

2011-24 Estimations of Tariff Equivalents for the Services Sectors

L. Fontagné, A. Guillin \& C. Mitaritonna

2011-23 Economic Impact of Potential Outcome of the DDA

Y. Decreux \& L. Fontagné

2011-22 More Bankers, more Growth? Evidence from OECD Countries

G. Capelle-Blancard \& C. Labonne

2011-21 EMU, EU, Market Integration and Consumption Smoothing

2011-20 Real Time Data and Fiscal Policy Analysis

J. Cimadomo

2011-19 On the inclusion of the Chinese renminbi in the SDR basket

A. Bénassy-Quéré \& D. Capelle

2011-18 Unilateral trade reform, Market Access and Foreign Competition: the Patterns of Multi-Product Exporters

M. Bas \& P. Bombarda

2011-17 The "Forward Premium Puzzle" and the Sovereign V. Coudert \& V. Mignon Default Risk

2011-16 Occupation-Education Mismatch of Immigrant Workers in Europe: Context and Policies

M. Aleksynska \& A. Tritah 
No

Title

2011-15 Does Importing More Inputs Raise Exports? Firm Level Evidence from France

2011-14 Joint Estimates of Automatic and Discretionary Fiscal Policy: the OECD 1981-2003

2011-13 Immigration, vieillissement démographique et financement de la protection sociale : une évaluation par l'équilibre général calculable appliqué à la France

2011-12 The Performance of Socially Responsible Funds: Does the Screening Process Matter?

2011-11 Market Size, Competition, and the Product Mix of Exporters

2011-10 The Trade Unit Values Database

2011-09 Carbon Price Drivers: Phase I versus Phase II Equilibrium

2011-08 Rebalancing Growth in China: An International Perspective

2011-07 Economic Integration in the EuroMed: Current Status and Review of Studies

2011-06 The Decision to Import Capital Goods in India: Firms' Financial Factors Matter

2011-05 FDI from the South: the Role of Institutional Distance and Natural Resources

2011-04b What International Monetary System for a fastchanging World Economy?

2011-04a Quel système monétaire international pour une économie mondiale en mutation rapide?

2011-03 China's Foreign Trade in the Perspective of a more Balanced Economic Growth

\section{Authors}

M. Bas

\& V. Strauss-Kahn

J. Darby \& J. Mélitz

X. Chojnicki \& L. Ragot

G. Capelle-Blancard \& S. Monjon

T. Mayer, M. Melitz \& G. Ottaviano

A. Berthou \& C. Emlinger

A. Creti, P.-A. Jouvet \& V. Mignon

A. Bénassy-Quéré, B. Carton \& L. Gauvin J. Jarreau

A. Berthou \& M. Bas

M. Aleksynska \& O. Havrylchyk

A. Bénassy-Quéré \& J. Pisani-Ferry

A. Bénassy-Quéré \& J. Pisani-Ferry

G. Gaulier, F. Lemoine \& D. Ünal 
No

Title

2011-02

The Interactions between the Credit Default Swap and the Bond Markets in Financial Turmoil

2011-01 Comparative Advantage and Within-Industry Firms M. Crozet \& F. Trionfetti Performance

\section{Authors}

V. Coudert \& M. Gex

(1)


Organisme public d'étude et de recherche en économie internationale, le CEPII est placé auprès du Centre d'Analyse Stratégique. Son programme de travail est fixé par un conseil composé de responsables de l'administration et de personnalités issues des entreprises, des organisations syndicales et de l'Université.

Les documents de travail du CEPII mettent à disposition du public professionnel des travaux effectués au CEPII, dans leur phase d'élaboration et de discussion avant publication définitive. Les documents de travail sont publiés sous la responsabilité de la direction du CEPII et n'engagent ni le conseil du Centre, ni le Centre d'Analyse Stratégique. Les opinions qui y sont exprimées sont celles des auteurs.

Les documents de travail du CEPII sont disponibles sur le site : http//www.cepii.fr. 